\title{
Guillain-Barré syndrome and chronic inflammatory demyelinating polyradiculoneuropathy after alemtuzumab therapy in kidney transplant recipients
}

Marieke van der Zwan, MD, Dennis A. Hesselink, MD, PhD, Esther Brusse, MD, PhD, Pieter A. van Doorn, MD, PhD, Martijn W.F. van den Hoogen, MD, PhD, Annelies E. de Weerd, MD, and Bart C. Jacobs, MD, PhD

Neurol Neuroimmunol Neuroinflamm 2020;7:e721. doi:10.1212/NXI.0000000000000721

Alemtuzumab is approved for the treatment of relapsing-remitting MS and is used off-label for patients with chronic lymphocytic leukemia and as induction and antirejection therapy in kidney transplant recipients. ${ }^{1}$ Guillain-Barré syndrome (GBS) or chronic inflammatory demyelinating polyradiculoneuropathy (CIDP) complicating alemtuzumab treatment was reported in 9 patients with hematologic malignancy or MS. ${ }^{1-3}$ The risk of GBS or CIDP in solid organ transplant recipients treated with alemtuzumab is unknown.

Rabbit antithymocyte globulin (rATG) is another T cell-depleting drug used to treat acute kidney allograft rejection. Only 1 patient was reported who developed GBS after rATG treatment for aplastic anemia. ${ }^{4}$ We found no reports of GBS or CIDP complicating rATG treatment in kidney transplant recipients. Here, we investigated the frequency, type, and outcome of GBS and CIDP in a single-center cohort of kidney transplant recipients treated with either alemtuzumab or rATG.

\section{Methods}

\section{Study design}

A retrospective analysis was performed of a cohort of kidney transplant recipients who received either alemtuzumab (Campath, Sanofi-Genzyme, Cambridge, MA) or rATG (Thymoglobulin, Sanofi-Genzyme) between 2002 and 2018 in the Erasmus MC, Rotterdam. Alemtuzumab was administered as a single dose of $30 \mathrm{mg}$ subcutaneously and $\mathrm{rATG}$ in a dose of $4 \mathrm{mg} / \mathrm{kg}$ and $\mathrm{nog} \mathrm{g} / \mathrm{kg}$.

\section{Statistical methods}

Continuous variables are presented as median and interquartile ranges (IQRs). The 95\% CIs were calculated with the modified Wald method. For statistical analysis, SPSS version 21 (SPSS Inc., Chicago, IL) was used.

Standard protocol approvals, registrations, and patient consents

The study was approved by the Erasmus MC Medical Ethical Review Board (number 2018-1430).

\section{Results}

Between 2002 and 2018, 2,788 patients received a kidney transplant at our center. Alemtuzumab was administered to $143(5.1 \%)$ patients and rATG to $108(3.9 \%)$ patients. The total follow-up period of patients treated with alemtuzumab was 3.0 years (IQR 1.7-4.1 years) for

\author{
Correspondence \\ Dr. van der Zwan \\ m.vanderzwan@erasmusmc.nl
}


Table Clinical characteristics, diagnosis, and outcome of patients with GBS and CIDP after alemtuzumab

\begin{tabular}{|c|c|c|c|}
\hline Case & 1 (GBS) & 2 (GBS) & 3 (CIDP) \\
\hline Sex & Male & Female & Male \\
\hline Age at onset symptoms (y) & 54 & 57 & 63 \\
\hline Primary kidney disease & Polycystic kidney disease & Reflux nephropathy & Polycystic kidney disease \\
\hline CMV status at transplantation & Seropositive & Seronegative & Seropositive \\
\hline Induction therapy & $\begin{array}{l}\text { Alemtuzumab ( } 30 \mathrm{mg}, 30 \text { days before transplantation, IVlg } 0.4 \mathrm{~g} / \mathrm{kg} \text { on the day of } \\
\text { transplantation), immunoabsorption }\end{array}$ & Basiliximab & Basiliximab \\
\hline Antirejection therapy & None & Alemtuzumab (30 mg) & Alemtuzumab (30 mg) \\
\hline $\begin{array}{l}\text { Immunosuppressive treatment at onset } \\
\text { symptoms }\end{array}$ & Tacrolimus/MMF/prednisolone 5 mg/d & Tacrolimus/MMF/prednisolone 2.5 mg/d & Tacrolimus/MMF/prednisolone 5 mg/d \\
\hline Diagnosis & GBS, level 2 of Brighton classification (no electrophysiologic studies available) & $\begin{array}{l}\text { GBS (AIDP), level } 1 \text { of Brighton } \\
\text { classification }\end{array}$ & $\begin{array}{l}\text { CIDP (fulfillment of clinical criteria and } \\
\text { definite electrophysiologic criteria EFNS/PNS } \\
\text { 2010) }\end{array}$ \\
\hline $\begin{array}{l}\text { Interval between alemtuzumab } \\
\text { treatment and symptoms (mo) }\end{array}$ & 4 & 8 & 42 \\
\hline Onset to maximum severity (d) & 21 & 10 & 90 \\
\hline Maximum mRS score (range 0-6) & 4 & 5 & 4 \\
\hline Maximum GBS disability score (range 0-6) & 4 & 5 & - \\
\hline EGOS (range 0-7) & 3.5 & 6.5 & - \\
\hline Treatment & IVlg $(0.4 \mathrm{~g} / \mathrm{kg})$ for 5 days & IVlg $(0.4 \mathrm{~g} / \mathrm{kg})$ for 5 days & $\begin{array}{l}2 \times \operatorname{IVlg}(0.4 \mathrm{~g} / \mathrm{kg}) \text { for } 5 \text { days, } 4 \text { sessions of } \\
\text { plasma exchange, methylprednisolone ( } 3 \times \\
1000 \mathrm{mg}) \text {, prednisone } 5 \mathrm{mg} \text { daily } \\
\text { (maintenance) }\end{array}$ \\
\hline mRS score after treatment & 1 & 6 & 1 \\
\hline GBS disability score after treatment of GBS & 1 & 6 & - \\
\hline Neurologic outcome at the last follow-up & Partial recovery (follow-up 1 year) & $\begin{array}{l}\text { Death ( } 6 \text { months later, due to } \\
\text { malignancy) }\end{array}$ & Full recovery (follow-up 3 years) \\
\hline
\end{tabular}

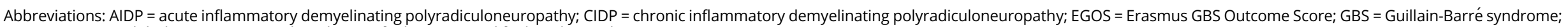


a total of 444.3 person-years. A tacrolimus-based immunosuppressive regimen was given to $92 \%$ of patients. Three patients $(2.1 \%, 95 \%$ CI $0.4 \%-6.3 \%)$ developed GBS or CIDP after alemtuzumab. Two patients fulfilled the diagnostic criteria for GBS, and 1 fulfilled the diagnostic criteria for CIDP. The clinical presentation and diagnostic findings of these patients are presented in the table. Laboratory tests, including clinical chemistry, serology, and virology, demonstrated no alternative diagnoses, and there was no recent Campylobacter jejuni or cytomegalovirus infection (PCR negative for cytomegalovirus). The total follow-up period for rATG-treated patients was 8.2 (IQR 6.3-11) years for a total of 829.4 person-years. Seventy-eight percent of patients received a tacrolimus-based immunosuppressive regimen. None of the patients treated with rATG (0\%, 97.5\% CI 0-4.1\%) developed GBS or CIDP.

\section{Discussion}

This study shows that $2.1 \%$ of patients treated with alemtuzumab developed GBS or CIDP. This is higher than the incidence rate of these neuropathies in the general population and of kidney transplant recipients not treated with alemtuzumab. ${ }^{5-7}$ Secondary autoimmunity after alemtuzumab appears to be mainly $\mathrm{B}$ cell driven. A mismatched reconstitution of $\mathrm{T}$ and $\mathrm{B}$ cells after alemtuzumab can lead to an expansion of $\mathrm{B}$ cells in the absence of appropriate $\mathrm{T}$-cell regulation. This may enable the escape of autoreactive B cells and production of pathogenic autoantibodies to self-antigens, which can lead to secondary autoimmunity, such as thyroiditis, idiopathic thrombocytopenic purpura, GBS, or CIDP. ${ }^{1}$

None of the patients treated with rATG developed GBS or CIDP. A possible explanation for the difference in the risk of developing these neuropathies with alemtuzumab is that the depletion of immune cells lasts longer after alemtuzumab. ${ }^{1}$ Alternatively, rATG may protect from GBS and CIDP.

Limitations of the current study are that we were unable to define the frequency of GBS and CIDP in kidney transplant recipients not treated with $\mathrm{T}$ cell-depleting therapy. Second, no causality between alemtuzumab and the risk of GBS or CIDP was demonstrated, and our findings may therefore relate to chance. Third, cytomegalovirus could have played a role in the development of GBS or CIDP because patients 1 and 3 were seropositive for cytomegalovirus at the time of transplantation. However, no signs of a reactivation were observed at the time the patients were diagnosed with GBS and CIDP. Fourth, we cannot exclude that the increased incidence of GBS and CIDP among alemtuzumab-treated patients may relate to the fact that in this group, more patients used tacrolimus as maintenance immunosuppression compared with the rATG cohort. Fifth, this observation is based on kidney transplant recipients who have several reasons to have an underlying neuropathy (i.e., renal insufficiency and diabetes mellitus), and it is uncertain whether it is also applicable to patients with MS.
In conclusion, alemtuzumab therapy in kidney transplant recipients may be associated with the development of GBS and CIDP. Clinicians should be alert for these neurologic complications in kidney transplant recipients treated with alemtuzumab.

\section{Study funding}

No sources of funding were used in the preparation of this manuscript.

\section{Disclosure}

DA Hesselink has received grant support, lecture, and consulting fees from Astellas Pharma and Chiesi Pharmaceuticals, a lecture fee from Hikma Pharma, and grant support from Bristol-Myers Squibb. PA van Doorn has received grant support from Baxter, Sanquin Plasma Products, and Grifols. $\mathrm{MvdH}$ has received grant lecture and consulting fees from Astellas Pharma, Amgen, Genzyme, MSD, Roche, Sanofi, and Vifor Pharmaceuticals. BC Jacobs has received grant support from Annexon Biosciences, Baxter, CSL Behring, Hansa Biopharma, and Grifols. The other authors declare no conflicts of interest. Go to Neurology.org/NN for full disclosures.

\section{Publication history}

Received by Neurology: Neuroimmunology \& Neuroinflammation November 25, 2019. Accepted in final form March 13, 2020.

\begin{tabular}{|c|c|c|}
\hline Name & Location & Contribution \\
\hline $\begin{array}{l}\text { Marieke van } \\
\text { der Zwan, MD }\end{array}$ & $\begin{array}{l}\text { Erasmus MC, University } \\
\text { Medical Center } \\
\text { Rotterdam, The } \\
\text { Netherlands }\end{array}$ & $\begin{array}{l}\text { Participated in the } \\
\text { research design, } \\
\text { acquisition of the data, } \\
\text { data analysis, and writing } \\
\text { of the manuscript }\end{array}$ \\
\hline $\begin{array}{l}\text { Dennis A. } \\
\text { Hesselink, } \\
\text { MD, PhD }\end{array}$ & $\begin{array}{l}\text { Erasmus MC, University } \\
\text { Medical Center } \\
\text { Rotterdam, The } \\
\text { Netherlands }\end{array}$ & $\begin{array}{l}\text { Participated in the } \\
\text { research design and } \\
\text { supervision and revision of } \\
\text { the manuscript }\end{array}$ \\
\hline $\begin{array}{l}\text { Esther } \\
\text { Brusse, MD, } \\
\text { PhD }\end{array}$ & $\begin{array}{l}\text { Erasmus MC, University } \\
\text { Medical Center } \\
\text { Rotterdam, The } \\
\text { Netherlands }\end{array}$ & $\begin{array}{l}\text { Participated in the revision } \\
\text { of the manuscript }\end{array}$ \\
\hline $\begin{array}{l}\text { Pieter A. van } \\
\text { Doorn, MD, } \\
\text { PhD }\end{array}$ & $\begin{array}{l}\text { Erasmus MC, University } \\
\text { Medical Center } \\
\text { Rotterdam, The } \\
\text { Netherlands }\end{array}$ & $\begin{array}{l}\text { Participated in the revision } \\
\text { of the manuscript }\end{array}$ \\
\hline $\begin{array}{l}\text { Martijn W.F } \\
\text { van den } \\
\text { Hoogen, MD, } \\
\text { PhD }\end{array}$ & $\begin{array}{l}\text { Erasmus MC, University } \\
\text { Medical Center } \\
\text { Rotterdam, The } \\
\text { Netherlands }\end{array}$ & $\begin{array}{l}\text { Participated in the revision } \\
\text { of the manuscript }\end{array}$ \\
\hline $\begin{array}{l}\text { Annelies E. de } \\
\text { Weerd, MD }\end{array}$ & $\begin{array}{l}\text { Erasmus MC, University } \\
\text { Medical Center } \\
\text { Rotterdam, The } \\
\text { Netherlands }\end{array}$ & $\begin{array}{l}\text { Participated in the revision } \\
\text { of the manuscript }\end{array}$ \\
\hline $\begin{array}{l}\text { Bart C. Jacobs, } \\
\text { MD, PhD }\end{array}$ & $\begin{array}{l}\text { Erasmus MC, University } \\
\text { Medical Center } \\
\text { Rotterdam, The } \\
\text { Netherlands }\end{array}$ & $\begin{array}{l}\text { Participated in the } \\
\text { research design and } \\
\text { supervision and revision of } \\
\text { the manuscript }\end{array}$ \\
\hline
\end{tabular}




\section{References}

1. van der Zwan M, Baan CC, van Gelder T, Hesselink DA. Review of the clinical pharmacokinetics and pharmacodynamics of alemtuzumab and its use in kidney transplantation. Clin Pharmacokinet 2018;57:191-207.

2. Avivi I, Chakrabarti S, Kottaridis P, et al. Neurological complications following alemtuzumab-based reduced-intensity allogeneic transplantation. Bone Marrow Transpl 2004;34:137-142.

3. Hradilek P, Woznicova I, Slonkova J, Lochmanova A, Zeman D. Atypical acute motor axonal neuropathy following alemtuzumab treatment in multiple sclerosis patient. Acta Neurol Belg 2017;117:965-967.
4. Kaya B, Davies CE, Oakervee HE, et al. Guillain Barre syndrome precipitated by the use of antilymphocyte globulin in the treatment of severe aplastic anaemia. J Clin Pathol 2005;58:994-995.

5. Willison HJ, Jacobs BC, van Doorn PA. Guillain-Barre syndrome. Lancet 2016;388: 717-727.

6. Ostman C, Chacko B. Guillain-Barre syndrome post renal transplant: a systematic review. Transpl Infect Dis 2019;21:e13021.

7. Echaniz-Laguna A, de Seze J, Chanson JB. Chronic inflammatory demyelinating polyradiculoneuropathy in solid organ transplant recipients: a prospective study. J Neurol Neurosurg Psychiatry 2012;83:699-705. 


\section{Neurology \\ Neuroimmunology \& Neuroinflammation}

Guillain-Barré syndrome and chronic inflammatory demyelinating polyradiculoneuropathy after alemtuzumab therapy in kidney transplant recipients Marieke van der Zwan, Dennis A. Hesselink, Esther Brusse, et al.

Neurol Neuroimmunol Neuroinflamm 2020;7;

DOI 10.1212/NXI.0000000000000721

This information is current as of April 16, 2020

Neurol Neuroimmunol Neuroinflamm is an official journal of the American Academy of Neurology.

Published since April 2014, it is an open-access, online-only, continuous publication journal. Copyright

Copyright $\left({ }^{\circ} 2020\right.$ The Author(s). Published by Wolters Kluwer Health, Inc. on behalf of the American

Academy of Neurology.. All rights reserved. Online ISSN: 2332-7812.

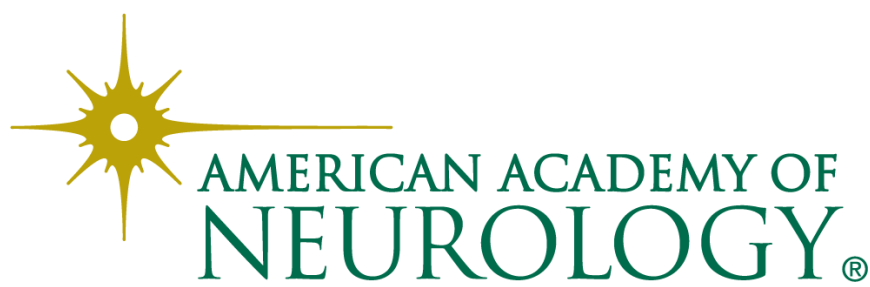




\section{Updated Information \& Services}

References

Citations

Subspecialty Collections

\section{Errata}

\section{Permissions \& Licensing}

Reprints including high resolution figures, can be found at: http://nn.neurology.org/content/7/4/e721.full.html

This article cites 7 articles, 2 of which you can access for free at: http://nn.neurology.org/content/7/4/e721.full.html\#\#ref-list-1

This article has been cited by 1 HighWire-hosted articles: http://nn.neurology.org/content/7/4/e721.full.html\#\#otherarticles

This article, along with others on similar topics, appears in the following collection(s):

All Clinical Neurology

http://nn.neurology.org//cgi/collection/all_clinical_neurology All Demyelinating disease (CNS)

http://nn.neurology.org//cgi/collection/all_demyelinating_disease_cns Chronic inflammatory demyelinating polyneuropathy http://nn.neurology.org//cgi/collection/chronic_inflammatory_demyeli nating_polyneuropathy

Guillain-Barre syndrome

http://nn.neurology.org//cgi/collection/guillainbarre_syndrome Multiple sclerosis

http://nn.neurology.org//cgi/collection/multiple_sclerosis

An erratum has been published regarding this article. Please see next page or:

/content/7/6/e882.full.pdf

Information about reproducing this article in parts (figures,tables) or in its entirety can be found online at:

http://nn.neurology.org/misc/about.xhtml\#permissions

Information about ordering reprints can be found online: http://nn.neurology.org/misc/addir.xhtml\#reprintsus

Neurol Neuroimmunol Neuroinflamm is an official journal of the American Academy of Neurology.

Published since April 2014, it is an open-access, online-only, continuous publication journal. Copyright

Copyright $\odot 2020$ The Author(s). Published by Wolters Kluwer Health, Inc. on behalf of the American Academy of Neurology.. All rights reserved. Online ISSN: 2332-7812.

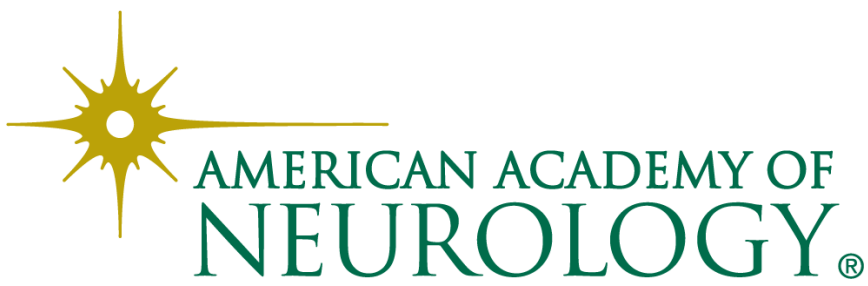




\section{Guillain-Barré syndrome and chronic inflammatory demyelinating polyradiculoneuropathy after alemtuzumab therapy in kidney transplant recipients}

Neurol Neuroimmunol Neuroinflamm 2020;7:e882. doi:10.1212/NXI.0000000000000882

In the Clinical/Scientific Note, "Guillain-Barré syndrome and chronic inflammatory demyelinating polyradiculoneuropathy after alemtuzumab therapy in kidney transplant recipients," by M. van der Zwan et al., the final sentence under the "Study Design" subheading of the Methods section should read "Alemtuzumab was administered as a single dose of $30 \mathrm{mg}$ subcutaneously and rATG in a dose of $4 \mathrm{mg} / \mathrm{kg}$." The publisher and authors regret the error.

\section{Reference}

1. van der Zwan M, Hesselink D, Brusse E, et al. Guillain-Barré syndrome and chronic inflammatory demyelinating polyradiculoneuropathy after alemtuzumab therapy in kidney transplant recipients. Neurol Neuroimmunol Neuroinflamm 2020;7:e721. doi: 10.1212/NXI.0000000000000721. 